Pendidikan Kimia Fakultas Keguruan dan Ilmu Pendidikan Universitas Mulawarman

http://jurnal.fkip.unmul.ac.id/index.php/bivalen



\title{
PENGARUH PENGGUNAAN MEDIA PEMBELAJARAN BONDING BOARD DENGAN MODEL PEMBELAJARAN QUANTUM TEACHING BERBASIS VISUAL, AUDITORI, KINESTETIK (VAK) TERHADAP PEMAHAMAN SISWA PADA MATERI IKATAN KIMIA \\ INFLUENCE OF USED BONDING BOARD WITH QUANTUM TEACHING METHOD BASIC VISUAL, AUDITORY, KINESTETIC (VAK) ON THE UNDERSTANDING ON CHEMICAL BONDING MATERIALS
}

\author{
Ani Suryani Simbolon*, Iis Intan Widiyowati, Ratna Kusumawardani \\ Program Studi Sarjana Pendidikan Kimia, Fakultas Keguruan dan Ilmu Pendidikan, Universitas Mulawarman, \\ Samarinda Kalimantan Timur, Indonesia \\ *Corresponding Author: anisimbolon62@gmail.com (+6281227186644)
}

\begin{abstract}
ABSTRAK
Penelitian ini bertujuan untuk mengetahui pengaruh penggunaan media pembelajaran bonding board dengan model pembelajaran quantum teaching berbasis Visual, Auditori, Kinestetik (VAK) terhadap tingkat pemahaman siswa SMA pada materi ikatan kimia. Populasi yang digunakan yaitu seluruh siswa kelas X SMA Negeri 5 Samarinda. Teknik pengambilan sampel menggunakan teknik purposive sampling, sehingga sampel yang digunakan adalah kelas X 4 dan kelas X 5. Teknik pengambilan data menggunakan teknik tes yang mencakup jenjang pemahaman kognitif siswa terdiri dari pengetahuan (knowledge), pemahaman (comprehension), penerapan (application), analisis (analysis), penilaian (evaluation), dan mencipta (create). Pengolahan data menggunakan Microsoft Excel dan SPSS 20. Hasil rata-rata kelas yang menggunakan model pembelajaran quantum teaching berbasis VAK adalah 72, 25 dan rata-rata kelas yang menggunakan model pembelajaran quantum teaching berbasis VAK dengan media bonding board adalah 74,96. Hasil penelitian menunjukkan bahwa tidak terdapat pengaruh penerapan media pembelajaran bonding board dengan model pembelajaran quantum teaching berbasis Visual, Auditori, Kinestetik (VAK) terhadap tingkat pemahaman siswa pada materi ikatan kimia.
\end{abstract}

Kata kunci: bounding board, quantum teaching, VAK, tingkat pemahaman

\section{ABSTRACT}

This study aims to determine the influence of application bonding board with quantum learning method based VAK toward student understanding levels in chemical bonding subject. The research populations were all of students class $X$ at SMAN 5 Samarinda. Sampling was done by purposive sampling technique and was chosen as the sampling experimental class are the class $X 4$ and X 5. The research used an instrumental design was six essay test, which include students cognitive levels are comprehension, application, analysis, evaluation, and synthesis. Score processed by using Microsoft Excel and SPSS 20 Program. The result on average classroom learning used quantum teaching based VAK is 72,25 and classroom learning used quantum teaching based VAK with bonding board is 74,96. The conclusion of this research showed that there were no influence of application bonding board with QT method based VAK towards student understanding levels in chemical bonding subject.

Keywords : bonding board, quantum teaching, VAK, understanding 


\section{PENDAHULUAN}

Materi yang diajarkan kepada siswa bukan hanya sebagai hafalan, namun siswa harus lebih mengerti akan konsep kimia, karena kimia merupakan ilmu yang penting dalam kehidupan kita sehari-hari. Pada mata pelajaran kimia yang sarat dengan konsep, dari konsep yang sederhana sampai konsep yang lebih kompleks dan abstrak sangat diperlukan pemahaman yang benar terhadap konsep dasar tersebut. Pada materi ikatan kimia, siswa dituntut untuk dapat membandingkan proses pembentukan ikatan ion ikatan kovalen ikatan koordinasi dan ikatan logam serta hubungannya dengan sifat fisika dari senyawa yang terbentuk. Sifat abstrak ini yang menjadi penyebab kesulitan siswa dalam memahami pembelajaran kimia. Salah satu penyebab rendahnya pemahaman siswa adalah penggunaan model pembelajaran yang tidak tepat. Ketidaktepatan pemilihan model pengajaran menyebabkan pembelajaran kimia mendapat kesan kurang baik dari siswa (Kusumaningtias, A, 2013). Penyajian materi kimia yang kurang menarik dan membosankan, akhirnya terkesan sulit dan memanfaatkan bagi siswa, akibatnya banyak siswa SMA yang kurang menguasai konsep-konsep dasar pelajaran kimia sehingga siswa tersebut tidak tertarik lagi mempelajarinya.

Penggunaan model pembelajaran yang tepat dapat membuat siswa dapat mengambil peran aktif dalam memilih, mengelola informasi, membangun hipotesisnya, memutuskan dan kemudian merefleksikan pengetahuannya itu dalam kehidupan sehari-hari, misalnya dengan model pembelajaran quantum teaching (Mahanal, S, 2010). Menurut Rusman (2012), quantum teaching mengubah belajar menjadi meriah. Quantum teaching juga mempertimbangkan gaya belajar siswa. Gaya belajar siswa dikelompokkan atas visual, auditorial dan kinestetik. Jika diberikan strategi yang sesuai dengan gaya belajarnya, siswa dapat berkembang lebih baik (Rakhmadhani, 2013). Gaya belajar tergantung dari orang yang belajar, karena setiap orang memiliki gaya belajar yang berbeda-beda. Penerapan model pembelajaran ini, siswa diharapkan mempunyai minat dan motivasi untuk belajar akan semakin meningkat. Penelitian mengenai penerapan model pembelajaran quantum teaching sudah pernah dilaksanakan, antara lain oleh Rofingah, S (2015) di SD Negeri 3 Karangsambung. Berdasarkan hasil penelitiannya menunjukkan bahwa model pembelajaran quantum teaching dapat meningkatkan hasil belajar siswa hingga $80 \%$ dan Amirotun, S 2016 di SD Negeri Sidomulyo dengan peningkatan nilai rata-rata hasil belajar sebesar $12,5 \%$. Cara lain yang dapat membuat siswa aktif dalam proses pembelajaran adalah dengan penggunaan media pembelajaran. Menurut Wahyuni, H (2012), media pembelajaran tidak hanya membantu guru dalam menyampaikan materi ajar, tetapi dengan penggunaan media pembelajaran yang berbeda dan menarik akan meningkatkan semangat belajar siswa. Salah satu media yang dapat digunakan adalah media bonding board. Media bonding board berupa papan yang terbuat dari seng, yang dilengkapi dengan kartu yang bertuliskan nama-nama unsur dan biji magnet. Penggunaannya siswa akan memasangkan kartu-kartu tersebut sehingga membentuk suatu senyawa. Siswa dituntut untuk menganalisis bagaimana senyawa tersebut dapat terbentuk serta bagaimana keterlibatan elektron dalam proses pembentukan ikatan.

Berdasarkan uraian di atas, peneliti merasa tertarik untuk melakukan penelitian dengan mengkombinasikan model pembelajaran quantum teaching dengan model pembelajaran bonding board. Penelitian yang dilakukan bertujuan untuk mengetahui apakah terdapat pengaruh penggunaan media pembelajaran bonding board dalam model pembelajaran quantum teaching berbasis Visual, Auditori, Kinestetik (VAK) terhadap pemahaman siswa pada materi ikatan kimia.

\section{METODE PENELITIAN}

Populasi yang digunakan dalam penelitian ini yaitu siswa kelas X SMA Negeri 5 Samarinda, yang berjumlah 318 siswa dan terbagi menjadi sepuluh kelas. Teknik pengambilan sampel yang digunakan pada penelitian ini adalah purposive sampling, berdasarkan rekapitulasi nilai dalam materi sebelumnya, yang memiliki nilai rata-rata sama (Suwarjana, K, 2016). Sampel yang digunakan dalam penelitian ini yaitu siswa kelas $\mathrm{X}$ 4 dan X 5 di SMA Negeri 5 Samarinda, Kalimantan timur, Indonesia. Penelitian ini menggunakan metode penelitian eksperimen. Penelitian ini menggunakan model pembelajaran quantum teaching berbasis Visual, Auditori, Kinestetik (VAK) dengan media pembelajaran bonding board untuk kelas X 5 dan kelas X 4 tanpa menggunakan media pembelajaran. Teknik pengumpulan data yang digunakan berupa tes hasil belajar yaitu posttest dan ulangan harian. Instrumen 
penelitian yang digunakan adalah soal tes berupa enam soal esai yang mencakup jenjang pemahaman kognitif siswa yang terdiri dari pengetahuan (knowledge) yang diberikan untuk mengukur kemampuan siswa dalam menyatakan kembali suatu nama, istilah ataupun pengertian suatu konsep yang dipelajari; pemahaman (comprehension) untuk mengukur kemampuan siswa dalam menjelaskan atau memberikan uraian yang lebih rinci tentang suatu konsep dengan kata-katanya sendiri, maupun membedakan, pengubah dan memberikan contoh suatu konsep; penerapan (application) untuk mengukur kemampuan siswa dalam menerapkan, menghubungkan, menghitung dan mengklasifikasikan; analisis (analysis) untuk mengukur kemampuan siswa dalam menganalisa informasi dan membagi-bagi atau menstruktur informasi ke dalam bagian yang lebih kecil untuk mengenali pola atau hubungannya dan mampu mengenali serta membedakan faktor penyebab dan akibat dari sebuah konsep; penilaian (evaluation) untuk mengukur kemampuan siswa dalam membentuk suatu pendapat mengenai suatu hal dengan pertanggungjawaban pendapat itu yang dapat dibedakan menjadi 2 kelompok yaitu, uji t variansi homogen dan uji $\mathrm{t}$ variansi heterogen (Arikunto 2009). Homogen atau heterogen kedua varians dapat diketahui dengan uji $\mathrm{F}$ (Harinaldi, 2005). Pengujian statistik dilakukan pada taraf signifikan $5 \%$.

\section{HASIL DAN PEMBAHASAN}

Kemampuan siswa dalam 6 jenjang pengetahuan kognitif dapat dilihat berdasarkan nilai rata-rata yang ditampilkan dalam Gambar 1 .

Soal jenjang pengetahuan dalam penelitian ini terletak dalam soal nomor satu pada posttest tiap pertemuan dan ulangan harian. Berdasarkan nilai rata-rata kedua kelas, dapat dilihat bahwa jenjang pengetahuan kelas kontrol lebih tinggi dari pada kelas eksperimen. Hal ini dikarenakan soal tipe jenjang pengetahuan ini disajikan dengan bahasa yang mudah dipahami oleh siswa sehingga siswa hanya diminta untuk mengingat konsep dan pengertian pengertian penting dalam pokok bahasan ikatan kimia (Ampuni, S. 1998). Konsep dasar ini lebih banyak didapatkan siswa dalam mengumpulkan data melalui penjelasan konsep

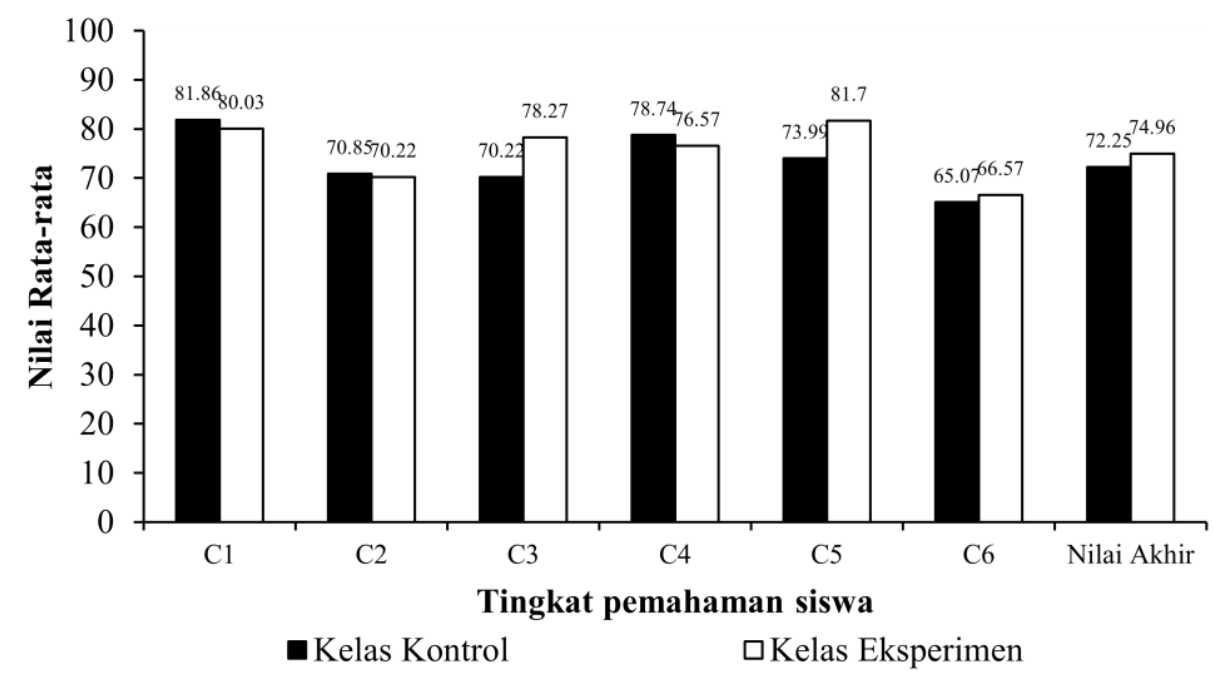

\section{Gambar 1. Nilai rata-rata kemampuan kognitif siswa}

berdasarkan kriteria tertentu yang dapat berupa pengecekan dan kritikan terhadap kesalahan pada prosedur atau hasil dalam menyelesaikan suatu masalah untuk mendekati jawaban yang benar; dan mencipta (create) untuk mengukur kemampuan siswa dalam mengeneralisasi ide baru, produk atau cara pandang yang baru. Data yang diperoleh diolah secara statistik dengan Microsoft Excel dan SPSS 20, melalui uji normalitas untuk melihat apakah data terdistribusi normal atau tidak, kemudian uji t untuk membandingkan nilai rata-rata kedua kelas. Uji $t$ oleh guru dan juga melalui buku atau sumber referensi lain. Kelas kontrol yang tidak menggunakan media pembelajaran bonding board memiliki waktu yang lebih banyak untuk memahami konsep dasar melalui penjelasan guru dan membaca buku, sehingga pada saat mengerjakan soal dengan jenjang pengetahuan siswa kelas kontrol yang tidak menggunakan media bonding board lebih mudah untuk mengerjakan soal. Penggunaan media bonding board ini lebih menekankan pada penerapan konsep daripada 
pengertian konsep dan prinsip dasar, sehingga siswa belum terbiasa untuk mengerjakan soal dalam jenjang pengetahuan yang menekankan pada hapalan untuk mengingat definisi dan prinsip dasar, soal jenjang pemahaman dalam penelitian ini terletak dalam soal nomor dua pada posttest dan ulangan harian. Berdasarkan nilai rata-rata kedua kelas dapat dilihat bahwa jenjang pengetahuan kelas kontrol lebih tinggi daripada kelas eksperimen. Hal ini disebabkan karena untuk dapat memahami konsep materi, siswa harus mengingat konsep dasarnya terlebih dahulu. Kelas kontrol memiliki waktu yang lebih banyak untuk memahami konsep dasar melalui pengamatan gambar dan tanya jawab. Proses tanya jawab ini melatih siswa untuk menjawab dengan pemahamannya sendiri. Soal jenjang penerapan dalam penelitian ini terletak dalam soal nomor tiga pada posttest dan ulangan harian. Berdasarkan nilai rata-rata kedua kelas, dapat dilihat bahwa jenjang pengetahuan kelas kontrol lebih rendah daripada kelas eksperimen. Pada tingkat soal ini siswa diminta untuk membuat struktur Lewis, pembentukan senyawa dan kepolaran yang sudah didiskusikan ketika menggunakan media bonding board. Tahapan-tahapan diskusi dengan menggunakan media bonding board membuat siswa lebih mengingat penerapan dari konsep materi itu sendiri hal ini sesuai dengan pendapat Bastable, S B (2002) bahwa penggunaan alat indra lebih banyak dalam proses pembelajaran diharapkan dapat membuat siswa lebih mudah memahami materi.

Soal jenjang analisis dalam penelitian ini terletak dalam soal nomor empat pada posttest dan ulangan harian. Berdasarkan nilai rata-rata kedua kelas, nilai kelas kontrol lebih tinggi dari pada kelas eksperimen. Pada jenjang analisis, siswa dituntut untuk menganalisis sebab-akibat dari suatu konsep. Siswa kelas eksperimen sudah dapat menganalisis secara garis besar, namun keterbatasan konsep dasar yang dimiliki siswa membuat hasil analisis kelas ini tidak maksimal. Pemahaman konsep dasar dan ketelitian yang kurang menyebabkan efektivitas penggunaan media pembelajaran bonding board ini tidak maksimal. Soal jenjang evaluasi dalam penelitian ini terletak dalam soal nomor lima pada posttest dan ulangan harian. Berdasarkan nilai ratarata kedua kelas, dapat dilihat bahwa jenjang menilai kelas kontrol lebih rendah daripada kelas eksperimen. Hal ini didukung dengan penggunaan media bonding board, karena soal pada tahap ini menuntut siswa untuk membuat pembentukan dan bentuk molekul senyawa baik itu ikatan ion ataupun kovalen yang sudah pernah mereka lakukan dengan menggunakan media tersebut. Penggunaan media bonding board yang lebih menekankan pada penerapan konsep daripada pengertian konsep dan prinsip dasar memudahkan siswa dalam mengerjakan soal dalam jenjang penilaian ini. Soal jenjang mencipta dalam penelitian ini terletak dalam soal nomor enam pada posttest ulangan harian. berdasarkan nilai rata-rata kedua kelas, dapat dilihat bahwa jenjang mencipta kelas eksperimen lebih tinggi daripada kelas kontrol. Siswa harus memiliki konsep dasar untuk dapat menciptakan (Ampuni, S, 1998). Konsep dasar dalam penggunaan media bonding board sangat membantu siswa, karena soal pada tahap ini menuntut siswa untuk membuat struktur dan proses persamaan reaksi pembentukan senyawa baik itu ikatan ion ataupun kovalen yang sudah pernah mereka lakukan dengan menggunakan media tersebut. Penggunaan media yang menuntut kreativitas siswa, membuat siswa terbiasa untuk mencoba dan membentuk sesuatu sesuai dengan ide mereka namun tetap berdasarkan konsep yang ada. Hal ini sesuai dengan pendapat Rahmadani (2013) bahwa penggunaan media membuat siswa lebih aktif dan memicu daya pikir untuk menemukan jawaban yang tepat dalam hal mencipta.

Berdasarkan uraian diatas terlihat bahwa media bonding board tidak memberikan pengaruh yang signifikan terhadap tingkat pemahaman secara keseluruhan, hal ini dikarenakan antara kelas kontrol dan kelas eksperimen sama-sama menggunakan model pembelajaran quantum teaching berbasis VAK. Media-media yang digunakan adalah media dapat memenuhi ketiga modalitas belajar. Siswa dengan modalitas belajar visual dapat terbantu dengan media gambar yang terdapat pada media flash dan video yang digunakan dalam materi ikatan kimia. Siswa dengan modalitas belajar auditori dibantu dengan media suara musik yang dapat merangsang minat belajar atau memberikan kesan yang menyenangkan, rileks dan nyaman bagi siswa. Siswa dengan modalitas kinestetik diperlukan media media pembelajaran yang dapat mengoptimalkan fungsi gerak siswa yaitu dengan praktikum. Menurut G.Salomon (2009), setiap media memiliki kemampuan untuk menyampaikan isi melalui sistem simbol tertentu. Lebih lanjut Salomon menyatakan bahwa efektivitas sebuah media bergantung pada kesesuaian dengan peserta didik atau pelajar, isi dan tugas. Berdasarkan uraian tersebut dapat disimpulkan bahwa media sangat penting dalam pembelajaran. Menurut Briggs media pembelajaran 
adalah sarana fisik untuk menyampaikan isi/materi pembelajaran seperti: buku, film, video dan sebagainya. Menurut National Education Association mengungkapkan bahwa media pembelajaran adalah sarana komunikasi dalam bentuk cetak maupun pandang dengar, termasuk teknologi perangkat keras dan posisi media pembelajaran. Jadi pembelajaran merupakan proses komunikasi dan berlangsung dalam satu sistem, maka media pembelajaran menempati posisi yang cukup penting sebagai salah satu komponen sistem pembelajaran. Tanpa media, komunikasi tidak akan terjadi dan proses pembelajaran sebagai proses komunikasi juga tidak akan bisa berlangsung secara optimal. Media pembelajaran adalah komponen integral dari sistem pembelajaran. Dari pendapat diatas disimpulkan bahwa media pembelajaran adalah segala sesuatu yang dapat menyalurkan pesan, dapat menstimulus pikiran, perasaan, dan kemauan siswa sehingga dapat mendorong terciptanya proses belajar pada diri siswa. Adapun tujuan dari media pembelajaran yaitu mempermudah proses belajar mengajar, meningkatkan efisiensi belajar mengajar, menjaga relevansi dengan tujuan belajar, membantu konsentrasi mahasiswa. Menurut Gagne komponen sumber belajar yang dapat merangsang siswa untuk belajar. Menurut Briggs wahana fisik yang mengandung materi instruksional. Menurut Schramm teknologi pembawa informasi atau pesan instruksional. Menurut Y. Miarso: Segala sesuatu yang dapat merangsang proses belajar siswa (Haryanto S.Pd, 2012).

Hasil nilai akhir rata-rata posttest dan ulangan harian dapat terlihat bahwa setelah pembelajaran ada perbedaan nilai rata-rata akhir. Perbedaan hasil perhitungan nilai rata-rata tingkat pemahaman siswa kelas X 5 sebesar 74,96 termasuk dalam kategori baik dan nilai rata-rata tingkat pemahaman siswa kelas X 4 sebesar 72,25 termasuk kategori baik. Data yang telah didapat diolah secara statistik menggunakan uji $\mathrm{N}$, uji $\mathrm{F}$ dan uji t. Uji dilakukan pada taraf signifikan 0,05 dan didapatkan $\mathrm{N}$ sebesar 0,517 karena $\mathrm{N}>0,05$, maka populasi terdistribusi normal. Dilakukan uji $\mathrm{F}$ diperoleh hasil $\mathrm{F}_{\text {hitung }}$ sebesar 1,992 dengan $\mathrm{F}_{\text {tabel }}$ sebesar 2,11; karena $\mathrm{F}_{\text {hitung }}<\mathrm{F}_{\text {tabel }}$ maka kedua sampel dinyatakan homogen. Dilakukan uji $\mathrm{t}$ diperoleh hasil $\mathrm{t}$ hitung $=$ 0,714 ; sedangkan nilai $\mathrm{t}$ tabel $=2,000$ pada taraf signifikan 5\%, maka diperoleh hasil $t_{\text {tabel }}<t_{\text {hitung }}$ maka $\mathrm{H}_{0}$ diterima dan $\mathrm{H}_{\alpha}$ ditolak. Ringkasan data setelah perlakuan dapat dilihat dalam Tabel 1 . Berdasarkan data tersebut, media pembelajaran bonding board tidak mempengaruhi pemahaman siswa secara keseluruhan pada materi ikatan kimia jika dikombinasikan dengan model pembelajaran quantum teaching berbasis Visual, Auditori, Kinestetik (VAK).

\section{SIMPULAN}

Berdasarkan hasil penelitian dapat disimpulkan bahwa tidak terdapat pengaruh penggunaan media pembelajaran bonding board dalam model pembelajaran quantum teaching berbasis Visual, Auditori, Kinestetik (VAK) terhadap tingkat pemahaman siswa pada materi ikatan kimia.

\section{UCAPAN TERIMAKASIH}

Terimakasih kepada bapak Sutrisno, M.Pd selaku kepala SMA negeri 5 Samarinda yang telah memberikan izin untuk melakukan penelitian.

\section{DAFTAR PUSTAKA}

Amirotun, S. (2016). Penerapan model pembelajaran Quantum Teaching dalam peningkatan pembelajaran IPS siswa kelas IV SD Negeri Sidomulyo. Kalam Cendekia. 4(2). 157-163.

Ampuni, S. (1998). Proses Kognitif dalam Pemahaman Bacaan. 17(2). 16-26

Arikunto. (2009). Prosedur Penelitian Suatu Pendekatan Praktik Edisi Revisi 6, Jakarta; Rineka Cipta

Baharudin dan Wahyuni. (2012). Teori Belajar dan Pembelajaran. Yogyakarta; Ar-Ruz Media.

Bastable, S B. (2002). Perawat Sebagai Pendidik Prinsip-Prinsip Pengajaran dan Pembelajaran. Jakarta; EGC

Harinaldi. (2005). Prinsip-Prinsip Statistik Untuk Teknik dan Sains. Jakarta; Erlangga.

Haryanto. (2012). Pengertian media Pembelajaran. Tersedia pada: http://www.belajarpsikologi.com/pengertianmedi a,pembelajaran.

Kusumaningtias, A. (2013). Pengaruh Problem Based Learning dipandu Strategi Number Heads Together terhadap kemampuan metakognitif, berpikir kritis dan kognitif biologi. 23(1), 33-47

Mahanal, S. (2010). Pengaruh pembelajaran Project Based Learning (PjBL) pada materi ekosistem terhadap sikap dan hasil belajar siswa SMAN 2 Malang 1(1).1-11

Rakhmadani, N. (2013). Pengaruh penggunaan metode Teams Games Tournament berbantuan media teka-teki silang dan ular tangga dengan motivasi belajar terhadap prestasi belajar siswa 
pada materi koloid kelas XI SMA Negeri 1 Simo tahun pelajaran 2011/2012. 2(4). 190-197

Rusman. (2012). Model-model Pembelajaran, Jakarta; Rajawali Pres.

Rofingah, S. (2015). Penerapan model Quantum Teaching dalam peningkatan pembelajaran IPA pada siswa kelas IV SD Negeri 3 Karangsambung, Surakarta; UNS, 3(4), 1-6

Salomon, G. (2009). Interaction of Media Cognition, and Learning Hillsdale, NJ: Lawrence Erlbaum Associates, Publishers.

Suwarjana, K. (2016). Statistik Kesehatan, Yogyakarta; Penerbit Andi 